\title{
Legitimasi Peraturan Pemerintah Pengganti Undang-Undang sebagai dalam Ratifikasi Perjanjian Internasional Tertentu
}

\author{
Fitri Lestari \\ University of Jember, Indonesia \\ fitrilestari.indonesian@gmail.com
}

\begin{abstract}
One of the challenges for the state is on how it carries out the ratification of international agreements. Indonesia has arduous tasks due to its late to ratify international conventions or agreements, even though such international instruments are needed for national interests. Based on Law Number 24 of 2000 on the International Agreement it is stipulated that the ratification of an international agreement in Indonesia uses two instruments, inter alia the law and presidential regulations. To adhere to this view, the compelling exigency is essential to analyze as it has been a challenge to overcome and anticipate obstacles in the ratification process and therefore it needs to set a period of time to ratify special international agreements. Ratification of international agreements through the Perppu (the government regulation in lieu of law) is very possible because its legitimacy is equivalent to the law but it should be the last priority.
\end{abstract}

KEYWORDS: Ratification, International Agreement, Perppu.

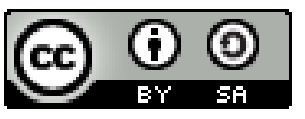

Copyright $\odot 2018$ by Author(s)

This work is licensed under a Creative Commons Attribution-ShareAlike 4.0 International License. All writings published in this journal are personal views of the authors and do not represent the views of this journal and the author's affiliated institutions.

\section{HOW TO CITE:}

Lestari, Fitri. "Legitimasi Peraturan Pemerintah Pengganti Undang-Undang sebagai dalam Ratifikasi Perjanjian Internasional Tertentu” (2018) 5:3 Lentera Hukum 365-388. 


\section{PENDAHULUAN}

Peraturan Pemerintah Pengganti Undang-Undang yang biasa disingkat menjadi Perppu merupakan salah satu produk hukum peraturan perundang-undangan yang berlaku di Indonesia berdasarkan Pasal 7 ayat (1) huruf c Undang-Undang Nomor 12 Tahun 2011 tentang Pembentukan Peraturan Perundang-Undangan. ${ }^{1}$ Keberadaan Perppu merefleksikan salah satu kekuasaan eksekutif dalam hal menghadapi keadaan kegentingan yang memaksa yang terjadi dalam negara. Dalam hierarki peraturan perundang-undangan Indonesia, Perppu memiliki kedudukan yang sejajar dengan undang-undang. Perppu ditetapkan oleh Presiden tanpa persetujuan DPR terlebih dahulu karena adanya "suatu hal ihwal kegentingan yang memaksa".

Penetapan Perppu yang pernah dilakukan selama ini dapat menjadi solusi untuk mengatasi masalah yang dalam keadaan genting dibutuhkan adanya aturan setingkat undang-undang untuk segera mengatasi masalah tersebut. Salah satu masalah yang masih dihadapi oleh Indonesia saat ini adalah masih adanya kendala dalam pelaksanaan ratifikasi perjanjian internasional. Indonesia masih sering mengalami kesulitan atau sering terlambat dalam meratifikasi konvensi atau perjanjian internasional meskipun instrumen internasional tersebut dibutuhkan bagi kepentingan nasional. Indonesia dinilai masih belum cepat tanggap dalam meratifikasi perjanjian internasional. Hal ini terbukti dengan banyaknya perjanjian internasional di berbagai bidang yang belum diratifikasi. $^{3}$

Kendala dalam proses ratifikasi perjanjian internasional di Indonesia, selain karena sulitnya mengharmoniskan standar internasional dengan hukum nasional dan belum adanya aturan tentang prosedur ratifikasi yang baku, juga disebabkan karena terjadinya kemacetan dalam proses ratifikasi perjanjian dengan undang-undang karena prosedur ratifikasi perjanjian internasional terkadang dapat berlangsung lama atau adanya penundaan dari pemerintah untuk meratifikasi perjanjian internasional tertentu sehingga proses ratifikasi perjanjian internasional ini menjadi tertunda dalam jangka waktu yang cukup lama, terkatung-katung bahkan tidak menentu, padahal tahap ratifikasi merupakan tahap yang sangat penting dalam perjanjian internasional dan pada keadaan tertentu harus segera dilakukan. ${ }^{4}$

Dalam Undang-Undang Nomor 24 Tahun 2000 tentang Perjanjian Internasional telah diatur bahwa apabila suatu perjanjian internasional ingin diberlakukan di Indonesia harus melalui proses pengesahan, salah satunya dengan ratifikasi. Proses ratifikasi suatu perjanjian internasional di Indonesia berdasarkan Undang-Undang

Indonesia, Undang-Undang Pembentukan Peraturan Perundang-Undangan, UU Nomor 12 Tahun 2011, Lembaran Negara Nomor 82 Tahun 2011, Tambahan Lembaran Negara Nomor 5234, Pasal 7 ayat (1) huruf c.

2 Maria Farida Indrati Soeprapto, Ilmu Perundang-Undangan Proses dan Teknik Pembentukannya. (Yogyakarta:Kanisius, 2007), hlm. 94.

3 Karmila Hippy, "Praktik Ratifikasi Perjanjian Internasional di Indonesia" dalam Jurnal Lex Administratum Volume I/Nomor 2/April-Juni/2013, hlm. 89.

4 Ibid, hlm. 100. 
tersebut menggunakan dua instrumen yaitu undang-undang dan keputusan Presiden yang sekarang sudah diganti menjadi peraturan Presiden. ${ }^{5}$

Dalam praktik ketatanegaraan selama ini, Perppu yang pernah ditetapkan oleh Presiden menunjukkan adanya kecenderungan penafsiran "kegentingan yang memaksa" sebagai keadaan mendesak yang perlu diatur dengan peraturan setingkat undangundang. Kemudian Putusan Mahkamah Konstitusi Nomor 138/PUU-VII/2009 telah menetapkan tiga syarat adanya kegentingan yang memaksa sebagaimana dimaksud oleh Pasal 22 ayat (1) UUD 1945. Pertama, adanya keadaan yaitu kebutuhan mendesak untuk menyelesaikan masalah hukum secara cepat berdasarkan undang-undang. Kedua, undang-undang yang dibutuhkan tersebut belum ada sehingga terjadi kekosongan hukum, atau ada undang-undang tetapi tidak memadai. Ketiga, kekosongan hukum tersebut tidak dapat diatasi dengan cara membuat undang-undang secara prosedur biasa karena akan memerlukan waktu yang cukup lama sedangkan keadaan mendesak tersebut perlu kepastian untuk diselesaikan.

Tidak dapat dipungkiri bahwa di masa yang akan datang berpotensi muncul suatu keadaan kegentingan yang memaksa yang mendesak pemerintah untuk segera melakukan ratifikasi terhadap perjanjian internasional tertentu dengan undangundang. Di masa yang akan datang, untuk mengantisipasi terjadinya kelambatan dalam ratifikasi perjanjian internasional di Indonesia, maka perlu untuk melakukan suatu tindakan cepat dan efisien dengan menentukan jangka waktu untuk melakukan ratifikasi tehadap perjanjian internasional tertentu khusus diterapkan di Indonesia sebagai upaya mengatasi masalah kelambatan tersebut atau meratifikasi suatu perjanjian internasional tertentu dengan Perppu sebagai solusi terakhir. Karena materi muatan Perppu sama dengan materi muatan undang-undang dan jika dibandingkan dengan undang-undang, prosedur pembentukan Perppu jauh lebih singkat. Berdasarkan uraian latar belakang tersebut, tulisan ini hendak mengkaji apakah suatu perjanjian internasional karena adanya hal ikhwal kegentingan memaksa dimungkinkan untuk diratifikasi dengan Perppu dan apakah Perppu sebagai produk hukum dalam meratifikasi perjanjian internasional memiliki legitimasi yang sama seperti undang-undang.

\section{RATIFIKASI PERJANJIAN INTERNASIONAL DENGAN PERATURAN PEMERINTAH PENGGANTI UNDANG-UNDANG}

\section{A. Hal Ikhwal Kegentingan yang Memaksa dalam Penetapan Peraturan Pemerintah Pengganti Undang-Undang}

Undang-Undang Dasar Negara Republik Indonesia Tahun 1945 mengatur tentang pembentukan Perppu, yakni dalam Pasal 22 ayat (1) disebutkan, pertama, dalam hal ikhwal kegentingan yang memaksa, Presiden berhak menetapkan peraturan

5 Shanti Rahmadsyah, Status Hukum UU Ratifikasi", http://www.hukumonline.com/klinik/detail/ lt4c69blcbd0492/status-hukum-uu-ratifikasi, diunduh 24 November 2017. 
pemerintah sebagai pengganti undang-undang; kedua eraturan pemerintah itu harus mendapat persetujuan Dewan Perwakilan Rakyat dalam persidangan yang berikut; ketiga, jika tidak mendapat persetujuan, maka peraturan pemerintah itu harus dicabut. ${ }^{6}$

Berdasarkan ketentuan tersebut, Undang-Undang Dasar Negara Republik Indonesia Tahun 1945 memberikan kewenangan kepada Presiden untuk menetapkan Perppu, namun kewenangan tersebut hanya dapat digunakan dalam hal ikhwal kegentingan yang memaksa. Meskipun kewenangan untuk membuat Perppu dimiliki oleh Presiden, namun Perppu tetap harus mendapatkan persetujuan dari DPR pada persidangan berikutnya yakni masa persidangan pertama DPR yang paling dekat dengan tanggal pada saat Perppu tersebut ditetapkan.

Putusan Mahkamah Konstitusi Nomor 138/PUU-VII/2009 telah menetapkan tiga syarat adanya kegentingan yang memaksa sebagaimana dimaksud oleh Pasal 22 ayat (1) Undang-Undang Dasar Negara Republik Indonesia Tahun 1945. Pertama, adanya keadaan yaitu kebutuhan mendesak untuk menyelesaikan masalah hukum secara cepat berdasarkan undang-undang. Kedua, undang-undang yang dibutuhkan tersebut belum ada sehingga terjadi kekosongan hukum, atau ada undang-undang tetapi tidak memadai. Ketiga, kekosongan hukum tersebut tidak dapat diatasi dengan cara membuat undang-undang secara prosedur biasa karena akan memerlukan waktu yang cukup lama sedangkan keadaan mendesak tersebut perlu kepastian untuk diselesaikan. ${ }^{7}$ Dalam pertimbangan hukum Mahkamah Konstitusi menjelaskan bahwa Perppu melahirkan norma hukum dan sebagai norma hukum baru dapat menimbulkan status hukum baru, hubungan hukum baru dan akibat hukum baru. Norma hukum tersebut lahir sejak Perppu ditetapkan dan nasib dari norma hukum baru tersebut tergantung kepada persetujuan DPR untuk menyetujui atau menolak norma hukum Perppu. Namun sebelum adanya keputusan DPR untuk menolak atau menyetujui Perppu, norma hukum tersebut adalah sah dan berlaku seperti undang-undang.

Oleh karena dapat menimbulkan norma hukum yang kekuatan mengikatnya sama dengan undang-undang, maka terhadap norma yang dimuat dalam Perppu tersebut Mahkamah Konstitusi dapat menguji apakah bertentangan secara materiil dengan Undang-Undang Dasar Negara Republik Indonesia Tahun 1945. Dengan demikian, Mahkamah Konstitusi berwenang untuk menguji Perppu terhadap UndangUndang Dasar Negara Republik Indonesia Tahun 1945 sebelum adanya penolakan atau persetujuan oleh DPR, dan setelah adanya persetujuan dari DPR karena Perppu tersebut telah menjadi undang-undang. ${ }^{8}$

Pasal 22 Undang-Undang Dasar Negara Republik Indonesia Tahun 1945 menyediakan pranata khusus dengan memberikan wewenang kepada Presiden untuk menetapkan Perppu apabila terjadi kekosongan undang-undang karena adanya berbagai hal dan proses untuk membentuk undang-undang yang sesuai dengan tata

Undang-Undang Dasar Negara Repuplik Indonesia Tahun 1945, UUD '45 dengan Penjelasan Hasil Amndemen Dilengkapi dengan Susunan Kabinet Indonesia Bersatu, (Jakarta: Abdi Pertiwi, 2004), hlm. 27. Putusan Mahkamah Konstitusi Republik Indonesia, Putusan Nomor 138/PUU-VII/2009, hlm. 19.

Ibid, hlm. 20-2l. 
cara atau ketentuan yang berlaku dalam pembuatan undang-undang memerlukan waktu yang cukup lama sedangkan kebutuhan hukum yang mendesak tersebut perlu kepastian untuk segera diselesaikan. ${ }^{9}$

Rumusan Pasal 22 ayat (1) Undang-Undang Dasar Negara Republik Indonesia Tahun 1945 jelas telah menyatakan bahwa peraturan pemerintah yang dimaksud adalah sebagai pengganti undang-undang yang artinya seharusnya materi tersebut diatur di dalam undang-undang tetapi karena hal ikhwal kegentingan yang memaksa, UndangUndang Dasar Negara Republik Indonesia Tahun 1945 memberikan hak kepada Presiden untuk membuat dan menetapkan Perppu. Penetapan Perppu memang di tangan Presiden yang artinya tergantung kepada penilaian subjektif Presiden, namun tidak berarti bahwa secara absolut tergantung pada penilaian subjektif Presiden, karena sebagaimana tiga syarat mengenai kegentingan memaksa yang telah dijelaskan dalam Putusan Mahkamah Konstitusi Nomor 138/PUU-VII/2009, penilaian subjektif Presiden harus didasarkan pada keadaan yang objektif yaitu tiga syarat tersebut sebagai parameter adanya kegentingan yang memaksa.

\section{B. Ratifikasi Perjanjian Internasional}

Ratifikasi merupakan persetujuan pemerintah atau kepala negara atas penandatanganan perjanjian internasional yang dilakukan oleh kuasa penuhnya (full power) yang telah ditunjuk. Ratifikasi dianggap sebagai penyampaian pernyataan formal oleh suatu negara mengenai persetujuannya untuk mengikatkan diri pada suatu perjanjian internasional. Pentingnya ratifikasi semakin meningkat dengan semakin berkembangnya sistem konstitusi pemerintahan yang memberi kekuasaan membuat perjanjian internasional kepada berbagai organ selain kepala negara. Pada masingmasing negara, prosedur ratifikasi yang diterapkan berbeda-beda antara negara yang satu dengan negara yang lain. Prosedur ratifikasi tingkat nasional, pengaturannya diserahkan pada hukum nasional masing-masing negara. ${ }^{10}$

Persetujuan untuk mengikatkan diri pada suatu perjanjian internasional berdasarkan Vienna Convention on The Law of Treaties 1969 dapat dilakukan dengan cara pertukaran instrumen perjanjian, ratifikasi, penerimaan, persetujuan atau aksesi, atau dengan cara lain yang disepakati oleh pihak dalam perjanjian. Secara umum, ketentuan ratifikasi yang berlaku dalam hukum internasional tercantum dalam Article 14 Vienna Convention on The Law of Treaties 1969. Namun, mengenai prosedur dan tata cara ratifikasi tersebut bagaimana harus dilakukan oleh negara-negara yang mengikatkan diri pada perjanjian, Vienna Convention on The Law of Treaties 1969 tidak mengatur. Kenyataannya prosedur ratifikasi ditentukan oleh hukum nasional masing-masing negara.

Ratifikasi perjanjian internasional di Indonesia dilakukan dengan dua instrumen hukum berdasarkan pada ketentuan Undang-Undang Nomor 24 Tahun 2000 tentang

\footnotetext{
9 Ibid.

10 Mohd. Burhan Tsani, Hukum dan Hubungan Internasional, (Yogyakarta : Liberty, 1990), hlm. 76-77.
} 
Perjajian Internasional, yakni pengesahan atau ratifkasi dalam bentuk undang-undang dan peraturan presiden.

\section{Ratifikasi dengan Undang-Undang}

Undang-Undang Nomor 24 Tahun 2000 tentang Perjanjian Internasional telah mengatur bahwa pengesahan atau ratifikasi suatu perjanjian internasional dilakukan dengan undang-undang dan peraturan Presiden. Ketentuan dalam Pasal 10 UndangUndang Nomor 24 Tahun 2000 tentang Perjanjian Internasional mengatur bahwa pengesahan suatu perjanjian internasional dilakukan dengan undang-undang apabila berkenaan dengan masalah politik, perdamaian, pertahanan, dan keamanan negara. Selain itu juga masalah-masalah yang berkenaan dengan perubahan wilayah atau penetapan batas wilayah Republik Indonesia, kedaulatan atau hak berdaulat negara, hak asasi manusia dan lingkungan hidup, pembentukan kaidah hukum baru, pinjaman dan/atau hibah luar negeri. Pengesahan atau ratifikasi perjanjian internasional dalam benuk undang-undang dilakukan bukan berdasarkan pada bentuk dan nomenclature perjanjian, namun berdasarkan materi perjanjian.

Pengesahan atau ratifikasi perjanjian internasional, setidaknya berdasarkan pada tiga peraturan yang menjadi dasar pelaksanaannya yaitu Undang-Undang Nomor 24 Tahun 2000 tentang Perjanjian Internasional, Undang-Undang Nomor 12 Tahun 2011 tentang Pembentukan Peraturan Perundang-Undangan, dan Peraturan Presiden Nomor 87 Tahun 2014 tentang Peraturan Pelaksanaan Undang-Undang Nomor 12 Tahun 2011 tentang Pembentukan Peraturan Perundang-Undangan. Adapun secara terperinci mengenai prosedur dan tata cara ratifikasi perjanjian internasional dengan undangundang dapat dilihat dalam buku Pedoman Praktis Direktorat Perjanjian Ekonomi dan Sosial Budaya, Kementerian Luar Negeri Republik Indonesia ${ }^{11}$. Prosedur pengesahan atau ratifikasi perjianjian internasional dengan undang-undang memiliki proses yang cukup panjang karena pada hakikatnya prosedur yang diterapkan hampir sama halnya dengan prosedur pembentukan undang-undang. Undang-Undang Nomor 24 Tahun 2000 tentang Perjanjian Internasional masih terlalu umum mengatur tentang ratifikasi dan belum mengatur secara tegas dan baku mengenai tata cara dan prosedur ratifikasi perjanjian internasional. ${ }^{12}$

Tidak selalu RUU permohonan ratifikasi yang diajukan oleh pemerintah diterima oleh DPR. DPR pernah menolak RUU permohonan ratifikasi yakni ratifikasi perjanjian kerjasama pertahanan Republik Indonesia dengan Singapura atau DCA (Defence Cooperation Agreement). DPR menolak meratifikasi DCA antara Pemerintah Republik Indonesia dengan Singapura yang sudah ditandatangani di Bali pada 27 Januari 2007.

1l Elmar Iwan Lubis, et al., Pedoman Praktis Pembuatan, Pengesahan,dan Penyimpanan Perjanjian Internasional Termasuk Penyiapan Full Powers dan Credentials, Direktorat Perjanjian Ekonomi dan Sosial Budaya, Direktorat Jenderal Hukum dan Perjanjian Internasional, Kementerian Luar Negeri 20ll, (Jakarta: Direktorat Perjanjian Ekonomi dan Sosial-Budaya, Ditjen Hukum dan Perjanjian Internasional, Kementerian Luar Negeri, RI, 2012), hlm. 6-8.

12 Karmila Hippy, "Praktik Ratifikasi Perjanjian Internasional di Indonesia" dalam Jurnal Lex Administratum Volume I/Nomor 2/April-Juni/2013, hlm. 98. 
DPR tidak mau mempertaruhkan kedaulatan dengan membiarkan negara lain mengacak-acak wilayah NKRI. Menurut Wakil Ketua Komisi I DPR Hajriyanto, perjanjian yang telah dibuat tersebut lebih banyak merugikan daripada keuntungan yang didapatkan. ${ }^{13}$

Sikap menolak atau membatalkan ratifikasi suatu perjanjian internasional tersebut, terdapat implikasi bagi negara yang menjadi pihak dalam perjanjian tersebut. Dalam hal ini adalah Indonesia dan Singapura. Maka pertama harus terlebih dulu dipahami konteks bagaimana suatu negara akan terikat dalam perjanjian internasional. Mengenai bagaimana suatu negara terikat dengan suatu perjanjian internasional, maka hal itu diatur dalam perjanjian itu sendiri yang umumnya menyatakan bahwa perjanjian tersebut akan mengikat para pihak apabila negara yang bersangkutan terlebih dahuku melakukan ratifikasi/aksesi terhadap perjanjian internasional tersebut. Dengan demikian, berarti bahwa suatu ratifikasi/aksesi merupakan tindakan hukum yang dilakukan oleh suatu negara untuk mengikatkan diri pada suatu perjanjian internasional. Hal ini sejalan dengan Article 2(b) Vienna Convention on The Law of Treaties 1969 dan Pasal 1 huruf b Undang-Undang Nomor 24 Tahun 2000 tentang Perjanjian Internasional. ${ }^{14}$

Mengenai penolakan DPR untuk meratifikasi DCA, DPR menolak sebelum adanya undang-undang tentang pengesahan perjanjian internasional tersebut. Jadi masih sebatas pernyataan sepakat dan penandatangan, belum terikat secara definitif karena belum ada instrumen ratifikasi terhadap perjanjian tersebut. Article 54(a) Vienna Convention on The Law of Treaties 1969 menagtur bahwa pengakhiran suatu perjanjian internasional dapat terjadi sesuai dengan ketentuan yang telah diatur dalam perjanjian atau setiap saat sesuai dengan persetujuan semua pihak sesudah berkonsultasi dengan negara-negara pihak yang ikut serta dalam perjanjian. Kemudian Article 56 Vienna Convention on The Law of Treaties 1969 juga menjelaskan bahwa apabila suatu perjanjian internasional tidak memuat mengenai ketentuan pengakhiran, pemutusan atau penarikan diri dari perjanjian internasional tersebut masih dapat dilakukan sepanjang para pihak sepakat menerima pengunduran diri yang dilakukan. ${ }^{15}$

Penolakan untuk meratifikasi DCA disampaikan dengan prosedur yang benar dan pembatalan perjanjian tersebut juga dilakukan harus atas kesepakatan kedua belah pihak. Hal ini dilakukan supaya hubungan kedua negara ini tetap baik dan kondusif. Apabila ratifikasi ditolak, tentu saja akibatnya pembicaraan harus dibuka lagi, artinya perlu ada lagi pembahasan-pembahasan mengenai hal tersebut. Perkembangannya, pembahasan yang dilakukan sejak penolakan ratifikasi oleh Indonesia belum ada titik temu bahkan tidak ada kemajuan. Penolakan ratifikasi tidak berarti merupakan suatu

\footnotetext{
13 AntaraNews.com, Fraksi DPR Tolak Ratifikasi Kerjasama Pertahanan RI-Singapura, https://www.antaranews.com/berita/65987/fraksi-dpr-tolak-ratifikasi-kerjasama-pertahanan-risingapura, diakses pada 14 Mei 2018.

14 Andi Sandi Ant.T.T dan Agustina Merdekawati, Konsekuensi Pembatalan Undang-Undang Ratifikasi Terhadap Keterikatan Pemerintah Indonesia pada Perjanjian Internasional, dalam Jurnal Mimbar Hukum, Volume 24, Nomor 23, Oktober 2012, hlm. 473.

15 Ibid.
} 
perbuatan yang melanggar hukum sebab wewenang untuk menolak ratifikasi dianggap sebagai atribut kedaulatan negara. Dalam hal tindakan DPR yang tidak mau meratifikasi DCA hingga saat ini, DPR tidak bisa disalahkan karena dalam perjanjian tersebut lebih banyak kerugian di pihak Indonesia. Maka wajar jika DPR tidak mau meratifikasi hinggasekarang dan mungkin tidak akan pernah melakukannya sampai isi kesepakatan yang merugikan itu diubah. ${ }^{16} \mathrm{Hal}$ ini menjadi pelajaran bagi pemerintah dan Menteri Pertahanan agar tidak gegabah dalam membuat perjanjian. Dalam perjanjian tersebut terdapat beberapa klausul yang dinilai sangat berpotensi mengancam kedaulatan NKRI. ${ }^{17}$

Sebagaimana diketahui bahwa proses ratifikasi suatu perjanjian internasional merupakan tahap yang sangat penting dalam proses pembuatan perjanjian internasional karena pada saat suatu perjanjian internasional diratifikasi, itu artinya negara yang bersangkutan terikat pada perjanjian tersebut. Maka sudah semestinya perlu ada suatu peraturan yang jelas, tegas dan baku yang mengatur tentang proses ratifikasi perjanjian internasional. Undang-Undang Nomor 24 Tahun 2000 tentang Perjanjian Internasional masih terlalu umum mengatur tentang perjanjian internasional.

Menurut Hassan Wirayuda, karena belum adanya undang-undang tentang ratifikasi maka pemerintah masih menentukan sendiri perjanjian internasional mana yang dibawa ke DPR untuk diratifikasi dalam bentuk undang-undang dan mana yang diratifikasi dengan Perpres. ${ }^{18}$ Selain itu, adanya masalah kelambatan dalam proses ratifikasi yang dialami selama ini masih belum bisa diatasi secara tuntas. Meratifikasi dengan Perppu dimungkinkan untuk mengatasi masalah kelambatan tersebut. Setidaknya mengurangi permasalahan dan kendala yang dialami pemerintah Indonesia dalam melakukan tindakan ratifikasi suatu perjanjian internasional, karena juga tidak menutup kemungkinan di masa yang akan datang ada suatu keadaan kegentingan yang memaksa sehingga pemerintah perlu melakukan tindakan cepat dan efisien untuk segera melakukan ratifikasi suatu perjanjian internasional tertentu yang mensyaratkan diratifikasi dengan undang-undang demi kemaslahatan rakyat.

\section{Ratifikasi dengan Peraturan Presiden}

Undang-Undang Nomor 24 Tahun 2000 tentang Perjanjian Internasional juga mengatur mengenai pengesahan perjanjian internasional dalam bentuk Peraturan Presiden. Dalam Undang-Undang Nomor 24 Tahun 2000 tentang Perjanjian Internasional tidak tertulis Peraturan Presiden, tetapi tertulis Keputusan Presiden. Namun keputusan Presiden saat ini sudah tidak tercantum dalam hierarki peraturan perundang-undangan Indonesia sejak diundangkannya Undang-Undang Nomor 10 Tahun 2004 tentang Pembentukan Peraturan Perundang-Undangan yang kini sudah diganti dengan Undang-Undang Nomor 12 Tahun 2011 tentang Pembentukan Peraturan Perundang-Undangan, sehingga secara otomatis keputusan Presiden diganti menjadi

\footnotetext{
16 Ibid.

17 AntaraNews.com, supra note 13.

18 Ibid, hlm. 99.
} 
peraturan Presiden. Aturan ini telah diterapkan sejak 20 Desember 2004 yakni ditandai dengan terbitnya Peraturan Presiden Nomor 4 Tahun 2004 tentang Pengesahan Protocol to Amend The ASEAN Framework Agreement on Services. ${ }^{19}$

Pengesahan atau ratifikasi perjanjian internasional dalam bentuk peraturan Presiden diatur dalam Pasal 11 Undang-Undang Nomor 24 Tahun 2000 tentang Perjajian Internasional bahwa pengesahan perjanjian internasional yang materinya tidak termasuk materi sebagaimana materi yang megharuskan ratifikasi dengan undang-undang, maka dilakukan dengan peraturan Presiden. Sama halnya dengan pengesahan atau ratifikasi dalam bentuk undang-undang, pengesahan atau ratifikasi perjanjian internasional dalam bentuk Peraturan Presiden setidaknya berdasarkan pada tiga peraturan yang menjadi dasar pelaksanaannya yaitu Undang-Undang Nomor 24 Tahun 2000 tentang Perjanjian Internasional, Undang-Undang Nomor 12 Tahun 2011 tentang Pembentukan Peraturan Perundang-Undangan, dan Peraturan Presiden Nomor 87 Tahun 2014 tentang Peraturan Pelaksanaan Undang-Undang Nomor 12 Tahun 2011 tentang Pembentukan Peraturan Perundang-Undangan.

Mengenai prosedur dan tata cara ratifikasi perjanjian internasional dengan Perpres juga dapat dilihat dalam buku pedoman praktis Direktorat Perjanjian Ekonomi dan Sosial Budaya, Kementerian Luar Negeri Republik Indonesia ${ }^{20}$. Jika dibandingkan dengan proses ratifikasi perjanian internasional dengan undang-undang, proses ratifikasi perjajian internasional dengan peraturan Presiden lebih singkat, karena perjanjian internasional yang diratifikasi dengan Perpres memerlukan penerapan dalam waktu singkat tanpa mempengaruhi peraturan perundang-undangan nasional. ${ }^{21}$

\section{B. Ratifikasi Perjanjian Internasional dengan Peraturan Pemerintah Pengganti Undang-Undang}

Substansi yang terkandung dalam Undang-Undang Nomor 24 tahun 2000 tentang Perjanjian Internasional memang tidak mengatur mengenai ratifikasi atau pengesahan perjanjian internasional dengan Peraturan Pemerintah Pengganti Undang-Undang, bahkan dalam Undang-Undang ini juga tidak satupun menyebutkan Perppu. Jika melihat persoalan yang dialami yakni adanya keterlambatan dan kemacetan dalam proses meratifikasi perjanjian internasional dengan undang-undang, maka menjadi dapat dimungkinkan untuk meratifikasi atau mengesahkan suatu perjanjian internasional dengan Perppu sebagai solusi terakhir. Perjanjian internasional yang diratifikasi dengan Perppu merupakan perjanjian internasional tertentu yakni yang memiliki syarat adanya keadaan kegentingan yang memaksa sehingga perlu untuk segera untuk melakukan tindakan ratifikasi terhadap perjanjian internasional tersebut. Namun ratifikasi dengan Perppu ini adalah solusi paling terakhir apabila upaya-upaya sebelumnya belum bisa mengatasi keadaan mendesak guna menghindari masalah kelambatan ratifikasi perjanjian internasional. Upaya yang dapat dilakukan sebelum

19 Sistem Informasi Perundang-Undangan Sekretariat Kabinet RI, Pengesahan Perjanjian Internasional, http://sipuu.setkab.go.id/perjanjian_internasional, diakses pada 4 April 2018.

20 Elmar Iwan Lubis, supra note 1l, hlm. 14 - 15.

21 I Wayan Parthiana, Hukum Perjanjian Internasional Bagian 2, (Bandung: Mandar Maju, 2005), hlm. 602. 
menggunakan Perppu sebagai instrumen ratifikasi adalah menentukan jangka waktu dalam meratifikasi perjanjian internasional khusus hanya diterapkan di Indonesia yang tujuannya untuk menghindari masalah kelambatan dalam ratifikasi perjanjian internasional di Indonesia.

Dalam menentukan jangka waktu ratifikasi perjanjian internasional tersebut, maka perlu diketahui rata-rata waktu yang diperlukan untuk membentuk undangundang pengesahan perjajian internasional sejak tanggal penandatangan perjanjian sampai tanggal pengundangan undang-undang tentang pengesahan atau ratifikasi perjanjian internasional. Berdasarkan beberapa data perjanjian internasional yang diratifikasi dengan undang-undang yang diperoleh dari sistem informasi perundangundangan Sekretariat Kabinet Republik Indonesia, rata-rata proses ratifikasi dilakukan 3 - 4 tahun untuk kemudian diundangkan. Untuk mengantisipasi adanya keterlambatan dalam meratifikasi suatu perjanjian internasional, perlu ada jangka waktu setidak-tidaknya 6 bulan atau paling lambat 1 tahun untuk menyiapkan instrumen ratifikasi perjanjian internasional dengan undang-undang sejak tanggal penandatanganan pejanjian internasional tersebut. Hal ini untuk menghindari kelambatan maupun keterlambatan yang pernah dialami Indonesia selama ini. Namun jika dalam keadaan yang benar-benar genting atau mendesak untuk segera melakukan ratifikasi, maka solusi terakhir dimungkinkan dilakukan ratifikasi dengan Perppu.

Untuk mengetahui apakah suatu Perppu dapat dibentuk untuk meratifikasi suatu perjanjian internasional, maka perlu dijabarkan mengenai suatu keadaan kegentingan yang memaksa dalam pembentukan Perppu tersebut dan bagaimana kualifikasi suatu perjanjian internasional yang dapat diratifikasi dengan Perppu. Untuk mengetahui adanya keadaan kegentingan yang memaksa, tentu tidak lepas dari tiga syarat yang tercantum dalam putusan Mahkamah Konstitusi Nomor 138/PUU-VII/2009 sebagai parameter untuk membentuk suatu Perppu. Syarat adanya keadaan kegentingan yang memaksa dalam pembentukan Perppu berdasarkan Putusan Mahkamah Konstitusi Nomor 138/PUU-VII/2009.

Pengesahan atau ratifikasi perjanjian internasional dengan Perppu tidak diatur dalam Undang-Undang Nomor 24 Tahun 2000 tentang Perjanjian Internasional bahkan di dalam undang-undang manapun tidak mengatur ratifikasi dalam bentuk Perppu. Di masa yang akan datang tidak menutup kemungkinan pemerintah perlu untuk segera melakukan ratifikasi terhadap perjanjian internasional tertentu yang mengharuskan diratifikasi dengan undang-undang, yakni perjanjian internasional yang memiliki syarat sebagaimana ratifikasi dengan undang-undang yang tercantum dalam Pasal 10 UndangUndang Nomor 24 Tahun 2000.

Di masa yang akan datang keadaan genting juga berpotensi terjadi melihat pertumbuhan dan perkembangan hubungan luar negeri juga semakin meningkat. Oleh karena itu, untuk mengurangi dan mengantisipasi adanya kelambatan dan kemacetan dalam proses ratifikasi dalam keadaan yang mendesak, ratifikasi perjanjian internasional dengan Perppu dimungkinkan untuk dilakukan sebagai solusi terakhir. Namun disisi lain, juga dibutuhkan suatu aturan tentang prosedur yang jelas dan baku 
mengenai proses dan tata cara ratifikasi karena di Indonesia belum ada undang-undang yang mengatur tentang ratifikasi secara khusus, maka juga perlu untuk melakukan perbaikan atau perubahan terhadap Undang-Undang Nomor 24 Tahun 2000 tentang Perjanjian Internasional.

Beberapa perjanjian internasional yang lambat diratifikasi oleh pemerintah Republik Indonesia diantaranya Maritime Labour Convention (MLC) ${ }^{22}$ dan International Convention Against the Taking of Hostages. ${ }^{23}$ Pemerintah terus didesak supaya segera meratifikasi Maritime Labour Convention (MLC). Kesatuan Pelaut Indonesia (KPI) sangat menyesalkan sikap pemerintah karena hingga tahun 2016 belum meratifikasi MLC yang telah diberlakukan di seluruh dunia sejak tahun 2014. Jika konvensi yang ditetapkan ILO (International Labour Organization) pada tahun 2006 tersebut tidak segera diratifikasi, peluang kerja bagi pelaut Indonesia di luar negeri akan hilang. Apabila hal tersebut terjadi, maka dampaknya adalah tingkat pengangguran di Indonesia akan semakin meningkat. Presiden KPI mendesak pemerintah untuk harus segera meratifikasi MLC setelah menghadiri sidang ILO yang membahas amandemen MLC dan Konvensi ILO Nomor 185 tentang Seafarers' Identity Document (SID) di Jenewa. ${ }^{24}$

Presiden KPI mengatakan bahwa lambatnya pemerintah meratifikasi MLC, akan berdampak besar bagi peluang kerja di luar negeri. Lapangan kerja bagi pelaut akan hilang karena perusahaan pelayaran di luar negeri akan merekrut pelaut dari negaranegara yang sudah meratifikasi MLC. Pelaut Indonesia yang habis kontrak juga akan sulit bekerja kembali di luar negeri. Ini akan sangat membahayakan karena akan menambah pengangguran. Di sisi lain, kapal-kapal Indonesia yang berlayar ke luar negeri pasti mengalami kesulitan, karena harus diperiksa oleh PSC (Port State Controle) di pelabuhan setempat. Bahkan kapal bisa ditahan, dan ini sudah banyak terjadi di Australia dan beberapa negara lainnya. Apabila kapal sampai ditahan karena belum memiliki sertifikat MLC, akan sangat merugikan pemilik atau operator kapal. Untuk menghindari masalah tersebut, banyak pemilik atau operator kapal mendaftarkan kapalnya di luar negeri yang sudah meratifikasi MLC, misalnya Singapura. Hal ini dilakukan agar kapalnya tidak menghadapi masalah di luar negeri, terutama di negara yang sudah meratifikasi MLC. ${ }^{25}$

Dalam sidang ILO yang berlangsung 8 - 10 Februari 2016, peserta dari 60 negara menyepakati dua amandemen MLC. Pertama, penambahan pengaturan tentang harassment dan bullying bagi pelaut. Kedua, penambahan waktu validasi sertifikasi yang semula 3 bulan menjadi 5 bulan. Dengan adanya amandemen MLC, menurut

22 Pikiran Rakyat, RI Terlambat Ratifkasi MLC, Pelaut Terancam, http://www.pikiranrakyat.com/nasional/2013/08/18/247050/ri-terlambat-ratifikasi-mlc-pelaut-terancam, diakses pada 9 Mei 2018 .

23 Okezone News, Marak Penyanderaan, Pemerintah Diminta Meratifikasi Perjanjian Internasional, https://news.okezone.com/read/2016/07/28/337/1449396/marak-penyanderaan-pemerintah-dimintaratifikasi-perjanjian-internasional, diakses pada 9 Mei 2018.

24 Redaksional KPI, Ratifikasi MLC Terkatung-katung, http://www.kpiunion.org/berita-ratifikasi-mlcterkatungkatung.html, diakses pada 13 Mei 2018.

25 Ibid. 
Hasudungan, posisi Indonesia yang belum meratifikasi MLC akan bertambah sulit. Selain harus mengikuti perkembangan amandemen, juga wajib mengantisipasi dampaknya terhadap hukum dan peraturan perundangan nasional. ${ }^{26}$

Pemerintah Indonesia juga didesak untuk segera meratifikasi atau melakukan persetujuan terhadap perjanjian internasional yakni International Convention Against the Taking of Hostages. Hal ini karena Indonesia sampai saat ini belum memiliki sebuah regulasi hukum nasional yang secara spesifik mengatur tentang perompakan. Maka sangat perlu dengan segera adanya perubahan-perubahan menyeluruh yang fundamental untuk menuju poros maritim dunia yang bebas dari perompakan. ${ }^{27}$

Selain itu, pada masa pemerintahan Presiden Susilo Bambang Yudhoyono, Indonesia pernah terlambat meratifikasi dua konvensi internasional tentang Hak Asasi Manusia yakni Konvensi Internasional tentang Hak Sipil dan Politik serta Konvensi Internasional tentang Hak Ekonomi, Sosial dan Budaya sehingga pada waktu itu pemerintah diminta untuk segera meratifikasi dua konvensi internasional tersebut. ${ }^{28}$ Direktur ELSAM menjelaskan bahwa dua konvensi ini merupakan pokok dari sekitar 25 instrumen konvensi tentang Hak Asasi Manusia. Selama ini Indonesia meratifikasi cabang-cabangnya, misalnya konvensi tentang anak, anti penyiksaan dan lain-lain. Maka dengan demikian penting bagi Indonesia untuk segera mengesahkan dua konvensi internasional tersebut yang telah diratifikasi oleh 85 negara anggota PBB. Masa ratifikasi untuk dua konvensi tersebut sebenarnya sudah ditutup sejak tahun 1976. Tapi meski sudah ditutup bukan berarti negara-negara yang ingin menjadi pihak dari perjanjian multilateral ini tidak bisa masuk, sebab dalam hukum internasional masih dimungkinkan negara-negara yang terlambat meratifikasi suatu konvensi internasional untuk ikut serta sebagai pihak. ${ }^{29}$

\section{LEGITIMASI PERATURAN PEMERINTAH PENGGANTI UNDANG- UNDANG SEBAGAI PRODUK HUKUM DALAM MERATIFIKASI PERJANJIAN INTERNASIONAL}

\section{A. Pembentukan Peraturan Pemerintah Pengganti Undang-Undang}

Undang-Undang Dasar Negara Republik Indonesia Tahun 1945 dalam Pasal 22 ayat (1) telah memberikan wewenang kepada Presiden untuk menetapkan Perppu. Selanjutnya, Undang-Undang Nomor 12 Tahun 2011 tentang Pembentukan Peraturan PerundangUndangan dalam Pasal 11 menyebutkan bahwa materi muatan yang ada dalam Perppu sama dengan materi muatan undang-undang. Undang-undang adalah peraturan yang didalam pembentukannya dilakukan oleh dua lembaga yaitu Dewan Perwakilan Rakyat

26 Ibid.

27 Okezone News, supra note 23.

28 HukumOnline.com, Pemerintah Diminta Segera Mengesahkan Dua Konvensi Internasional tentang HAM, http://www.hukumonline.com/berita/baca/holl3221/pemerintah-diminta-segera-mengesahkan-duakonvensi-internasional-tentang-ham, diakses pada 9 Mei 2018.

29 Ibid. 
dengan Persetujuan Presiden seperti yang diatur dalam Pasal 5 ayat (1) dan Pasal 20 Undang-Undang Dasar Negara Republik Indonesia Tahun 1945. Berbeda dengan Perppu yang dalam pembentukannya hanya dilakukan oleh Presiden saja dibantu oleh Menterinya yang terkait dengan Perppu yang akan dibentuk, namun bukan berarti DPR tidak punya andil sama sekali dalam Perppu. DPR mempunyai amanat untuk memberikan keputusan terhadap Perppu pada saat sidang DPR berikutnya yang waktunya terdekat dengan waktu ketika Perppu ditetapkan.

Jika undang-undang yang dibutuhkan adalah persetujuan Presiden, maka untuk Perppu yang dibutuhkan adalah persetujuan dari DPR sebagai lembaga legislatif. Namun selama belum ada keputusan persetujuan atau penolakan dari DPR, Perppu tetap berlaku secara sah dalam waktu yang terbatas antara awal penetapannya sampai masa sidang DPR yang terdekat. Sedangkan undang-undang, setelah diundangkan sudah dapat langsung berlaku dan mengikat umum, tidak perlu menunggu persetujuan lagi dari pihak manapun. Dengan demikian, meskipun Pasal 11 Undang-Undang Nomor 12 ahun 2011 tentang Pembentukan Peraturan Perundang-Undangan menyebutkan materi muatan Perppu sama dengan undang-undang yakni bahwa undang-undang dan Perppu memiliki persamaan dalam hal materi muatan atau substansi, namun keduanya memiliki perbedaan dalam hal proses pembentukan dan jangka waktu keberlakuannya.

Proses pembentukan Perppu berjalan lebih singkat dibandingkan dengan proses pembentukan undang-undang, mengingat pembentukan Perppu dilakukan dalam keadaan genting atau mendesak. ${ }^{30}$ Pasal 53 Undang-Undang Nomor 12 Tahun 2011 tentang Pembentukan Peraturan Perundang-Undangan menyatakan bahwa ketentuan mengenai tata cara penyusunan Rancangan Peraturan Pemerintah Pengganti UndangUndang diatur dengan Peraturan Presiden. Saat ini telah berlaku Peraturan Presiden Nomor 87 Tahun 2014 tentang Peraturan Pelaksanaan Undang-Undang Nomor 12 Tahun 2011 tentang Pembentukan Peraturan Perundang-Undangan.

Berdasarkan Pasal 57 Perpres Nomor 87 Tahun 2014, dalam hal ikhwal kegentingan yang memaksa, Presiden menetapkan Peraturan Pemerintah Pengganti Undang-Undang. Selanjutnya Presiden menugaskan penyusunan rancangan Perppu kepada Menteri yang tugas dan tanggung jawabnya sesuai dengan materi yang akan diatur dalam Perppu tersebut sebagai Pemrakarsa. Dalam penyususnan rancangan Perppu tersebut, Pemrakarsa berkoordinasi dengan Menteri atau pimpinan lembaga pemerintah nonkementerian dan/atau pimpinan lembaga terkait. Setelah rancangan Perppu selesai disusun oleh Pemrakarsa kemudian disampaikan kepada Presiden untuk ditetapkan. ${ }^{31}$

Selanjutnya pada Pasal 60 dan 61 Perpres Nomor 87 Tahun 2014 menyebutkan bahwa selain menyusun rancangan Perppu, Pemrakarsa juga menyusun RUU tentang penetapan Perppu menjadi undang-undang dan menyusun RUU tentang pencabutan

30 Maria Farida Indrati Suprapto, "Ilmu Perundang-Undangan Proses dan Teknik Pembentukannya", (Yogyakarta: Kanisius, 2007), hlm. 81.

31 Indonesia, Peraturan Presiden Republik Indonesia Peraturan Pelaksanaan Undang-Undang Nomor 12 Tahun 2011 tentang Pembentukan Peraturan Perundang-Undangan, Perpres Nomor 87 Tahun 2014, Lembaran Negara Republik Indonesia Tahun 2014 Nomor 199, hlm. 18 - 19. 
Perppu yang memuat materi yang mengatur segala akibat hukum dari pencabutan Perppu. Dalam menyusun RUU tentang penetapan Perppu dan RUU tentang pencabutan Perppu, Pemrakarsa membentuk panitia antarkementerian dan/atau antarnonkementerian, kemudian apabila RUU tersebut selesai selanjutnya disampaikan kepada Menteri untuk dilakukan pengharmonisasian, pembulatan, dan pemantapan konsepsi. Setelah itu, Menteri menyampaikan kepada Pemrakarsa hasil pengharmonisasian, pembulatan, dan pemantapan konsepsi untuk disampaikan kepada Presiden. $^{32}$

\section{B. Keputusan Dewan Perwakilan Rakyat terhadap Peraturan Pemerintah Pengganti Undang-Undang}

Berdasarkan Pasal 22 ayat (2) Undang-Undang Dasar Negara Republik Indonesia Tahun 1945 juncto Pasal 52 ayat (1) Undang-Undang Nomor 12 Tahun 2011 tentang Pembentukan Peraturan Perundang-Undangan mengatur bahwa Perppu harus mendapatkan persetujuan/harus diajukan ke DPR dalam persidangan yang berikut. Setelah terbitnya Perppu, DPR diberikan amanat oleh konstitusi untuk melakukan legislative/political review terhadap Perppu yang telah dikeluarkan oleh Presiden. Pada tahap inilah norma subjektif yang diterbitkan dalam hal ikhwal kegentingan yang memaksa diuji konstitusionalitasnya. ${ }^{33}$ Selanjutnya Pasal 52 ayat (2) Undang-Undang Nomor 12 Tahun 2011 mengatur bahwa Perppu yang diajukan kepada DPR dilakukan dalam bentuk pengajuan RUU tentang penetapan Perppu menjadi undang-undang. Kemudian Pasal 52 ayat (3) Undang-Undang Nomor 12 Tahun 2011 mengatur bahwa DPR hanya memberikan persetujuan atau tidak memberikan persetujuan terhadap Perppu.

Berdasarkan ketentuan Pasal 52 ayat (4) Undang-Undang Nomor 12 Tahun 2011, apabila Perppu yang diajukan kepada DPR mendapatkan persetujuan DPR dalam rapat paripurna, maka selanjutnya Perppu ditetapkan menjadi undang-undang. Berikutnya di ayat (5) menentukan bahwa apabila Perppu yang diajukan kepada DPR tidak mendapatkan persetujuan DPR atau DPR menolak Perppu tersebut dalam rapat paripurna, maka Perppu tersebut harus dicabut dan harus dinyatakan tidak berlaku. Atas Perppu yang dinyatakan harus dicabut tersebut, DPR atau Presiden mengajukan RUU tentang pencabutan Perppu yang isinya mengatur segala akibat hukum dari pencabutan Perppu dan selanjutnya RUU tentang pencabutan Perppu tersebut ditetapkan menjadi undang-undang tentang Pencabutan Perppu. ${ }^{34}$

Mengenai Perppu yang dibentuk dengan tujuan untuk meratifikasi perjanjian internasional berlaku juga ketentuan berdasarkan pada Undang-Undang Nomor 12 Tahun 2011 yakni apabila Perppu ratifikasi tersebut mendapatkan persetujuan DPR,

32 Ibid.

33 Ibnu Sina Chandranegara, "The Review of Government Regulation in Lieu of Law Regarding Constitutional Authority Dispute among The State Institutions" dalam Jurnal Yudisial Vol.5 No.l, April 2012: 1-16, hlm. 11.

34 Indonesia, Undang-Undang Pembentukan Peraturan Perundang-Undangan, UU Nomor 12 Tahun 2011, Lembaran Negara Nomor 82 Tahun 201l, Tambahan Lembaran Negara Nomor 5234, Pasal 52. 
maka selanjutnya Perppu tersebut ditetapkan menjadi undang-undang, dan apabila Perppu ratifikasi perjanjian internasional tersebut tidak mendapat persetujuan DPR, maka Perppu tersebut harus dicabut dan dinyatakan tidak berlaku. Namun sejak Perppu tersebut ditetapkan oleh Presiden dan DPR belum memberikan keputusannya untuk memberikan persetujuan atau tidak memberikan persetujuan terhadap Perppu tersebut, maka Perppu ratifikasi perjanjian internasional tersebut berlaku secara sah.

Masalahnya adalah ketika DPR menolak atau tidak memberikan persetujuannya terhadap Perppu ratifikasi tersebut. Apabila DPR tidak memberikan persetujuan, maka Perppu tersebut harus dicabut dan ratifikasi terhadap perjanjian internasional tersebut tidak dilakukan. Keputusan DPR menolak suatu Perppu dapat dikarenakan dengan dua alasan. Pertama, karena pembentukan Perppu tersebut dianggap tidak dalam keadaan genting atau memaksa. Jika penolakan karena alasan ini, maka itu artinya masih dimungkinkan atau ada jangka waktu yang cukup untuk meratifikasi perjanjian internasional tersebut dengan undang-undang. Kedua, karena ada substansi yang bertentangan dengan Undang-Undang Dasar Negara Republik Indonesia Tahun 1945 atau materi dalam perjanjian internasional tersebut bertentangan dengan UndangUndang Dasar Negara Republik Indonesia Tahun 1945. Maka itulah alasan diperlukannya ketelitian yang serius sebelum meratifikasi suatu perjanjian internasional.

Jika DPR tidak memberikan persetujuan, maka dampak yang akan terjadi bukan hanya Perppu dicabut dan dinyatakan tidak berlaku tetapi juga dapat menyebabkan komitmen dan keseriusan Indonesia dalam melaksanakan perjanjian internasional akan dipertanyakan, karena sebagaimana telah kita pahami bahwa tahap ratifikasi merupakan tahap yang sangat penting dari proses pembuatan perjanjian internasional karena pada tahap inilah suatu negara mengikatkan dirinya secara definitif pada suatu perjanjian internasional.

Keikutsertaan suatu negara pada suatu perjanjian internasional tidak dapat dipaksakan karena tidak ada kewajiban suatu negara untuk selalu meratifikasi suatu perjanjian internasional. Apabila timbul keadaan suatu negara merasa dirugikan oleh suatu perjanjian internasional, maka negara dapat mengajukan permohonan penarikan diri (withdrawal) dari perjanjian internasional tersebut. Mundurnya suatu negara dari suatu perjajian bilateral berakibat sama dengan pengakhiran perjanjian. Namun dalam perjanjian multilateral, menarik diri atau mundur dari suatu perjanjian internasional tidak otomatis menjadikan perjanjian internasional itu berakhir karena sangat memungkinkan negara-negara yang lain masih ingin tetap melanjutkan eksistensi perjanjian internasional tersebut. ${ }^{35}$

Berdasarkan Article 54 Vienna Convention on The Law of Treaties 1969 menyatakan bahwa penghentian atau penarikan diri suatu negara dari perjanjian internasional dapat dilakukan setiap saat setelah melakukan konsultasi dengan negara pihak yang

35 Sefriani, Pengakhiran Sepihak Perjanjian Perdagangan Internasional, dalam PADJAJARAN Jurnal Ilmu Hukum, Volume 2 Nomor 1 Tahun 2015, hlm. 89. 
lain. ${ }^{36}$ Permasalahan yang muncul adalah apabila dalam suatu perjanjian internasional tidak diatur tentang hak dan prosedur bagi negara peserta untuk menarik diri atau mengakhiri perjanjian internasional tersebut. Apabila hal yang demikian terjadi, maka berlaku ketentuan Article 56 Vienna Convention on The Law of Treaties yang mengatur, pertama; A treaty which contains no provision regarding its termination and which does not provide for denunciation or withdrawal is not subject to denunciation or withdrawal unless: it is established that the parties intended to admit the possibility of denunciation or withdrawal; or a right of denunciation or withdrawal may be implied by the nature of the treaty. Kedua, a party shall give not less than twelve months' notice of its intention to denounce or withdraw from a treaty under paragraph 1.

Berdasarkan ketentuan dalam Article 56 tersebut, apabila suatu perjanjian internasional tidak memuat aturan tentang penarikan diri atau pengakhiran perjanjian internasional, maka tidak dibolehkan negara mengajukan apegunduran diri atau penarikan sepihak, kecuali jika negara pihak yang lain dalam perjanjian internasional tersebut berkenan untuk mengizinkan atau secara tersirat memungkinkan suatu pihak untuk mengundurkan diri dari perjanjian internaional tersebut. Pada umumnya suatu perjanjian internasional telah mengatur sendiri syarat dan mekanisme pembatalan, penarikan diri atau pengakhiran perjanjian tersebut. Untuk penarikan diri secara sepihak dari suatu negara, maka harus mematuhi prosedur yang diatur dalam perjanjian internasional tersebut atau melalui prosedur yang diatur dalam Vienna Convention on The Law of Treaties 1969. Perjanjian internasional disahkan dengan kesepakatan bersama, maka pengakhiran perjanjian internasional tersebut juga harus dilakukan dengan kesepakatan bersama. Ketentuan lain yang harus disepakati adalah pemenuhan kewajiban yang harus dilakukan berdasarkan perjanjian sebelum negara yang bersangkutan dinyatakan resmi keluar dari kesepakatan dalam perjajian internasional tersebut. $^{37}$

Penggunaan hukum nasional sebagai alasan untuk menarik diri dari suatu perjanjian internasional dapat dijustifikasi berdasarkan Article 46 dan Article 62 Vienna Convention on The Law of Treaties 1969 yang penerapannya tidak mudah. Article 46 Vienna Convention on The Law of Treaties 1969. Pertama, a State may not invoke the fact that its consent to be bound by a treaty has been expressed in violation of a provision of its internal law regarding competence to conclude treaties as invalidating its consent unless that violation was manifest and concerned a rule of its internal law of fundamental importance. Kedua, a violation is manifest if it would be objectively evident to any State conducting itself in the matter in accordance with normal practice and in good faith.

Ketentuan berdasarkan Article 46 tersebut hanya dapat digunakan apabila terdapat kesalahan proses keikutsertaan suatu negara dalam suatu perjanjian

\footnotetext{
36 Article 54 Vienna Convention on The Law of Treaties: The termination of a treaty or the withdrawal of a party may take place: (a) in conformity with the provisions of the treaty; or (b) at any time by consent of all the parties after consultation with the other contracting States.

37 Sefriani, supra note 35, hlm. 102.
} 
internasional yang ternyata melanggar hukum domestik atau hukum nasionalnya yang fundamental. Adapun Article 62 Vienna Convention on The Law of Treaties 1969, Pertama, a fundamental change of circumstances which has occurred with regard to those existing at the time of the conclusion of a treaty, and which was not foreseen by the parties, may not be invoked as a ground for terminating or withdrawing from the treaty unless; kedua, the existence of those circumstances constituted an essential basis of the consent of the parties to be bound by the treaty; ketiga, the effect of the change is radically to transform the extent of obligations still to be performed under the treaty; keempat, a fundamental change of circumstances may not be invoked as a ground for terminating or withdrawing from a treaty, if the treaty establishes a boundary; or if the fundamental change is the result of a breach by the party invoking it either of an obligation under the treaty or of any other international obligation owed to any other party to the treaty. Kelima, if, under the foregoing paragraphs, a party may invoke a fundamental change of circumstances as a ground for terminating or withdrawing from a treaty it may also invoke the change as a ground for suspending the operation of the treaty.

Berdasarkan ketentuan Article 62 ini adalah tentang rebus sic stantibus. Asas rebus sic stantibus yakni atas dasar kenyataan adanya perubahan-perubahan yang vital di dalam negeri dari salah satu negara sebagai pihak yang menandatangani, maka negara tersebut memiliki hak untuk menarik diri dari perjanjian internasional tersebut. Article 62 tersebut hanya dapat digunakan apabila terjadi suatu perubahan keadaan yang tidak terdapat pada saat pembentukan perjanjian. Perubahan tersebut merupakan keadaan yang fundamental bagi perjanjian tersebut dan tidak dapat diramalkan sebelumnya oleh para pihak dan adanya perubahan tersebut berakibat radikal sehingga mengubah lingkup kewajiban yang harus dilaksanakan menurut perjanjian internasional tersebut. Namun asas ini tidak dapat digunakan pada perjanjian perbatasan wilayah. Meskipun secara eksplisit tidak disebutkan tentang penggunaan hukum nasional atau kepentingan nasional, Article 48, Article 49, Article 50, Article 51, Article 52, Article 60 dan Article 61 Vienna Convention on The Law of Treaties 1969 juga dapat digunakan untuk mengakhiri perjanjian secara sepihak dengan syarat adanya kesepakatan dari negara pihak yang lain. ${ }^{38}$

\section{Pengujian Yudisial ke Mahkamah Konstitusi terhadap Peraturan Pemerintah Pengganti Undang-Undang}

Berdasarkan Pasal 24C ayat (1) Undang-Undang Dasar Negara Republik Indonesia Tahun 1945 junctis Pasal 1 angka 3 huruf a Undang-Undang Nomor 8 Tahun 2011 tentang Perubahan Atas Undang-Undang Nomor 24 Tahun 2003 tentang Mahkamah Konstitusi, dan Pasal 29 ayat (1) Undang-Undang Nomor 48 Tahun 2009 tentang Kekuasaan Kehakiman, salah satu kewenangan konstitusional Mahkamah Konstitusi adalah menguji undang-undang terhadap Undang-Undang Dasar.

38 Ibid. 
Dalam praktik yang dilakukan oleh Mahkamah Konstitusi sebagaimana dalam Putusan Nomor 138/PUU-VII/2009, ternyata tidak hanya undang-undang yang menjadi wewenang pengujian (judicial review) Mahkamah Konstitusi, tetapi juga termasuk Perppu. Formil Perppu bukanlah undang-undang, tetapi materiilnya adalah sama dengan undang-undang, karena materi muatan Perppu sama dengan materi muatan undang-undang sebagaimana telah ditegaskan dalam Pasal 11 Undang-Undang Nomor 12 Tahun 2011 tentang Pembentukan Peraturan Perundang-Undangan. Hal tersebut juga dapat dibuktikan dengan materi muatan Perppu yang dapat membatalkan, mengubah atau menambah ketentuan undang-undang.

Dalam Putusan Mahkamah Konstitusi Nomor 138/PUU-VII/2009, Mahkamah Konstitusi mempertimbangkan bahwa karena Perppu dapat menimbulkan norma hukum yang kekuatan mengikatnya sama dengan undang-undang, maka norma yang terdapat dalam Perppu tersebut, Mahkamah Konstitusi dapat menguji apakah bertentangan secara materiil dengan Undang-Undang Dasar Negara Republik Indonesia Tahun 1945. Jika suatu materi muatan peraturan perundang-undangan adalah sama dengan materi muatan undang-undang, maka pengujian peraturan perundang-undangan itu menjadi wewenang Mahkamah Konstitusi walaupun formil bukan undang-undang. ${ }^{39}$ Dengan dasar pertimbangan tersebut, Perppu yang secara formil bukanlah undang-undang tetapi karena materi muatan atau norma yang terkandung di dalamnya merupakan materi muatan atau norma undang-undang, maka Perppu dapat menjadi objek pengujian oleh Mahkamah Konstitusi.

Pada tahun 201l, Mahkamah Konstitusi pernah menolak permohonan mengenai pengujian Undang-Undang ratifikasi perjanjian internasional yakni Undang-Undang Nomor 38 Tahun 2008 tentang Pengesahan Charter of the Association of Southeast Asian Nations (Piagam Perhimpunan Bangsa-Bangsa Asia Tenggara) terhadap UndangUndang Dasar Negara Republik Indonesia Tahun 1945.

Dalam putusan tersebut, Mahkamah Konstitusi mempertimbangkan bahwa Undang-Undang mempunyai kekuatan hukum mengikat atas substansi yang diatur dalam undang-undang tersebut dan mengikat terhadap pihak-pihak yang membuat perjanjian, dalam hal ini adalah negara-negara yang membuatnya atau yang menyatakan mengikatkan diri dengan perjanjian tersebut. Karena undang-undang berlaku sebagai norma hukum, maka negara Indonesia dan negara lain, dalam hal ini negara ASEAN wajib terikat secara hukum oleh Undang-Undang Nomor 38 Tahun 2008. Persoalannya apakah memang hal tersebut benar, bagaimana mungkin suatu negara berdaulat harus tunduk kepada undang-undang negara lain. Apabila ada negara lain yang memberi bentuk perjanjian internasional menurut hukum nasionalnya dalam bentuk undangundang, apakah Indonesia secara serta merta harus terikat dengan undang-undang negara lain tersebut, tentu saja tidak. ${ }^{40}$

Kewajiban yang dibebankan kepada suatu negara oleh perjanjian internasional tidaklah lahir karena perjanjian internasional tersebut telah disahkan sebagai undang-

\footnotetext{
39 Ibid, hlm. 21.

40 Mahkamah Konstitusi, Putusan Nomor 33/PUU-IX/201l, hlm. 194.
} 
undang oleh pihak negara lain, tetapi kewajiban tersebut lahir karena para pihak dalam hal ini negara-negara sebagai subjek hukumnya telah menyetujui secara bersama-sama perjanjian internasional tersebut. Hal ini sesuai dengan asas pacta sunt servanda. Berdasarkan Article 38 ayat (1) Statute of the International Court of Justice, perjanjian internasional merupakan sumber hukum yang kedua setelah kebiasaan internasional, sedangkan undang-undang suatu negara tidak disebut sebagai sumber hukum internasional. ${ }^{41}$

Kemudian mengenai pengujian ratifikasi perjanjian internasional yang dilakukan dalam bentuk Perppu. Perppu yang diajukan untuk judicial review ke Mahkamah Konstitusi apabila sebelumnya Perppu tersebut telah melalui tahap political review oleh DPR, maka tidak menjadi masalah karena pada saat itu Perppu telah menjadi undangundang. Masalahnya jika Perppu tersebut diuji oleh Mahkamah Konstitusi sebelum disidangkan dan direview oleh DPR. Karena konsekuensi logisnya yakni apabila dalam putusan Mahkamah Konstitusi Perppu tersebut dibatalkan, terlebih apabila terdapat substansi yang bertentangan dengan konstitusi, maka akan timbul pertanyaan bagaimana nasib kewajiban yang dimiliki DPR untuk menguji Perppu pada persidangan berikutnya apabila Perppu tersebut telah diuji oleh Mahkamah Konstitusi, karena sifat putusan Mahkamah Konstitusi adalah final dan mengikat. Jelas bahwa apabila putusan Mahkamah Konstitusi membatalkan Perppu maka Perppu tersebut dinyatakan tidak dapat berlaku dan selanjutnya tidak perlu lagi disidangkan di DPR karena putusan Mahkamah Konstitusi sudah final dan mengikat.

Berikutnya adalah apabila yang diuji ke Mahkamah Konstitusi tersebut adalah Perppu ratifikasi perjajian internasional, maka sama halnya jika yang diuji adalah ratifikasi dalam bentuk undang-undang karena materi yang dimuat dalam Perppu sama dengan undang-undang. Perppu ratifikasi perjanjian internasional yang telah melalui tahap persidangan DPR, kemudian DPR memberikan persetujuannya, maka Perppu tersebut selanjutnya menjadi Undang-Undang. Dan apabila DPR menolak Perppu tersebut, maka Perppu tersebut harus dicabut dan ratifikasi terhadap perjanjian internasional tersebut tidak dilakukan karena pasti keputusan menolak yang dilakukan DPR karena ada substansi yang bertentangan dengan Undang-Undang Dasar Negara Republik Indonesia Tahun 1945 atau tidak dianggap dalam sebagai keadaan mendesak. Maka itulah alasan diperlukannya ketelitian sebelum meratifikasi suatu perjanjian internasional.

Berdasarkan pada Pasal 24 C Undang-Undang Dasar Negara Republik Indonesia Tahun 1945, secara normatif Pasal tersebut dapat dimaknai bahwa Mahkamah Konstitusi juga berwenang menguji Undang-Undang tentang Pengesahan Perjanjian Internasional yang bertentangan dengan Undang-Undang Dasar Negara Republik Indonesia Tahun 1945. Sudut pandang yang dipakai Mahkamah Konstitusi dalam melakukan judicial review adalah sudut pandang Undang-Undang Dasar Negara Republik Indonesia Tahun 1945. Kebenaran yang dianut Mahkamah Konstitusi adalah

$41 \quad$ Ibid, hlm. 195. 
kebenaran konstitusi yakni Undang-Undang Dasar Negara Republik Indonesia Tahun 1945.

Menurut Hakim Konstitusi Maria Farida mengatakan bahwa permohonan pengujian terhadap substansi dalam Undang-Undang tentang Pengesahan Perjanjian Internasional tidak mungkin dapat terjadi, karena tidak terdapat materi muatan dalam ayat, Pasal, dan/atau bagian Undang-Undang tersebut yang dapat dipertentangan dengan Undang-Undang Dasar Negara Republik Indonesia Tahun 1945. Begitu pula dengan Perppu yang materi muatannya sama dengan undang-undang. Dengan demikian, sudah seharusnya dalam meratifikasi suatu perjanjian internasional, pemerintah harus lebih selektif dalam memasukkan perjanjian internasional ke dalam hukum nasional. Selain Perppu ratifikasi perjanjian internasional sebagai cara untuk mengatasi masalah kelambatan dan kemacetan dalam proses ratifikasi dalam keadaan kegentingan yang memaksa, namun juga penting diperhatikan untuk sangat teliti sebelum melakukan ratifikasi.

Pemerintah harus terlebih dahulu harus mempertimbangkan untung rugi untuk membuat perjanjian internasional dengan negara lain atau masuk/ikut serta dengan perjanjian internasional yang telah ada. Apabila perjanjian internasional tidak memberikan keuntungan apapun bagi suatu negara, bahkan apabila justru menimbulkan kerugian, sudah semestinya negara tidak mengikatkan diri pada perjanjian yang demikian dan kalau suatu negara bermaksud untuk selalu mendapatkan keuntungan saja dari suatu perjanjian internasional atas kerugian negara lain tanpa harus berkorban, maka pihak negara lain pun tidak akan menyetujui perjanjian yang demikan, prinsip resiprositas (timbal balik) mendasari kesediaan suatu negara untuk mengikatkan diri dengan negara lain. ${ }^{42}$

\section{KESIMPULAN}

Peraturan Pemerintah Pengganti Undang-Undang merupakan salah satu produk hukum yang ditetapkan oleh Presiden dalam keadaan kegentingan yang memaksa. Putusan Mahkamah Konstitusi Nomor 138/PUU-VII/2009 telah menetapkan tiga syarat adanya kegentingan yang memaksa sebagaimana dimaksud oleh Pasal 22 ayat (1) UUD Negara Republik Indonesia Tahun 1945. Pertama, adanya keadaan yaitu kebutuhan mendesak untuk menyelesaikan masalah hukum secara cepat berdasarkan undangundang. Kedua, undang-undang yang dibutuhkan tersebut belum ada sehingga terjadi kekosongan hukum, atau ada undang-undang tetapi tidak memadai. Ketiga, kekosongan hukum tersebut tidak dapat diatasi dengan cara membuat undang-undang secara prosedur biasa karena akan memerlukan waktu yang cukup lama sedangkan keadaan mendesak tersebut perlu kepastian untuk diselesaikan. Undang-undang Nomor 24 tahun 2000 tentang perjanjian Internasional tidak mengatur pengesahan atau ratifikasi perjanjian internasional dengan Perppu, namun meratifikasi perjanjian internasional dengan Perppu dimungkinkan untuk dilakukan sebagai solusi terakhir apabila di masa

42 Mahkamah Konstitusi, supra note 40, hlm. 190. 
yang akan datang terjadi suatu keadaan kegentingan yang memaksa yang sangat mendesak pemerintah untuk segera meratifikasi suatu perjanjian internasional tertentu yang mensyaratkan diratfikasi dengan undang-undang.

Berdasarkan hierarki peraturan perundang-undangan Indonesia yang tercantum dalam Pasal 7 ayat (1) Undang-Undang Nomor 12 tahun 2011 tentang Pembentukan Peraturan Perundang-Undangan, kedudukan Perppu sejajar dengan undang-undang dan materi muatan Perppu adalah sama dengan materi muatan undang-undang. Perbedaan antara undang-undang dan Perppu adalah bahwa undang-undang dibentuk oleh Dewan Perwakilan Rakyat dengan persetujuan Presiden dan dalam keadaan pemerintahan yang normal, sedangkan Perppu dibentuk sendiri oleh Presiden tanpa persetujuan Dewan Perwakilan Rakyat dalam keadaan pemerintahan tidak normal yakni dalam kegentingan yang memaksa. Perppu yang dibentuk dengan tujuan untuk meratifikasi perjanjian internasional berlaku juga ketentuan berdasarkan pada UndangUndang Nomor 12 Tahun 201l. Sejak Perppu tersebut ditetapkan oleh Presiden dan DPR belum memberikan keputusannya untuk memberikan persetujuan atau tidak memberikan persetujuan terhadap Perppu tersebut, maka Perppu ratifikasi perjanjian internasional tersebut berlaku secara sah. Apabila Perppu ratifikasi tersebut mendapatkan persetujuan DPR, maka selanjutnya Perppu tersebut ditetapkan menjadi undang-undang. Namun apabila DPR menolak Perppu tersebut, maka Perppu tersebut harus dicabut dan ratifikasi terhadap perjanjian internasional tersebut tidak dilakukan karena pasti keputusan menolak yang dilakukan DPR bisa karena tidak dianggap keadaan genting atau karena ada substansi yang bertentangan dengan Undang-Undang Dasar Tahun 1945. Oleh sebab itu diperlukannya ketelitian sebelum meratifikasi suatu perjanjian internasional. Dalam Putusan Mahkamah Konstitusi Nomor 138/PUUVII/2009, Perppu dapat menjadi objek pengujian oleh Mahkamah Konstitusi.

Tahap pengesahan atau ratifikasi dalam perjanjian internasional merupakan tahap yang sangat penting, maka Undang-Undang Nomor 24 Tahun 2000 tentang Perjajnjian Internasional seharusnya mengatur secara lebih jelas dan baku khususnya mengenai prosedur, praktik, dan tata cara pengesahan/ratifikasi perjanjian internasional sehingga perlu untuk melakukan perubahan terhadap UU Nomor 24 Tahun 2000 tentang Perjanjian Internasional dengan beberapa alasan. Pertama, belum ada perubahan dan penjelasan tentang pengesahan Perjanjian internasional dengan Keputusan Presiden yang sekarang diganti dengan Peraturan Presiden. Kedua, belum ada aturan yang baku tentang prosedur dan tata cara ratifikasi perjanjian internasional. Ketiga, perlunya mencantumkan aturan mengenai langkah yang harus ditempuh pemerintah apabila dalam keadaan kegentingan yang memaksa harus segera meratifikasi suatu perjanjian internasional yang materinya mensyaratkan dilakukan dengan undang-undang, sedangkan prosedur ratifikasi dengan undang-undang membutuhkan waktu yang cukup lama.

Bagi pemerintah seharusnya sesegera mungkin untuk mempersiapkan rancangan undang-undang atau peraturan Presiden guna meratifikasi suatu perjanjian internasional setelah menyatakan sepakat dan mengikatkan diri dalam suatu perjanjian 
internasional tersebut sehingga tidak menimbulkan adanya keadaan mendesak di kemudian hari yang pada akhirnya untuk mengatasi situasi genting dimungkinkan untuk mengesahkan perjanjian internasional tersebut dengan Perppu. Meratifikasi perjanjian internasional dengan Perppu disini adalah sebagai solusi dalam keadaan kegentingan yang memaksa. Selain itu, juga harus sangat teliti dalam mengkaji perjajian internasional yang akan diratifikasi, sehingga substansi atau aturan yang tercantum dalam perjanjian internasional tersebut dapat dijamin tidak akan berbenturan dengan atauran hukum yang berlaku di Indonesia sehingga tidak berpotensi untuk diajukan judicial review ke Mahkamah Konstitusi.

\section{DAFTAR PUSTAKA}

AntaraNews, Fraksi DPR Tolak Ratifikasi Kerjasama Pertahanan RI-Singapura, https:/www.antaranews.com/berita/65987/fraksi-dpr-tolak-ratifikasi-kerjasamapertahanan-ri-singapura, diakses pada 14 Mei 2018.

Burhan Tsani, Mohd., Hukum dan Hubungan Internasional. (Yogyakarta : Liberty, 1990).

Elmar Iwan Lubis, et al., Pedoman Praktis Pembuatan, Pengesahan,dan Penyimpanan Perjanjian Internasional Termasuk Penyiapan Full Powers dan Credentials, Direktorat Perjanjian Ekonomi dan Sosial Budaya, Direktorat Jenderal Hukum dan Perjanjian Internasional, Kementerian Luar Negeri 2011, (Jakarta: Direktorat Perjanjian Ekonomi dan Sosial-Budaya, Ditjen Hukum dan Perjanjian Internasional, Kementerian Luar Negeri, Republik Indonesia, 2012).

Farida Indrati Soeprapto, Maria, Ilmu Perundang-Undangan Proses dan Teknik Pembentukannya. (Yogyakarta: Kanisius, 2007).

Hippy, Karmila, "Praktik Ratifikasi Perjanjian Internasional di Indonesia" dalam Jurnal Lex Administratum Volume I/Nomor 2/April-Juni/2013.

Hukum Online, Pemerintah Diminta Segera Mengesahkan Dua Konvensi Internasional tentang HAM, http://www.hukumonline.com/berita/baca/holl3221/pemerintahdiminta-segera-mengesahkan-dua-konvensi-internasional-tentang-ham, diakses pada 9 Mei 2018.

Ibnu Sina Chandranegara, "The Review of Government Regulation in Lieu of Law Regarding Constitutional Authority Dispute among The State Institutions" dalam Jurnal Yudisial Vol.5 No.1, April 2012: 1-16.

Okezone News, Marak Penyanderaan, Pemerintah Diminta Meratifikasi Perjanjian Pikiran Rakyat, RI Terlambat Ratifkasi MLC, Pelaut Terancam, http://www.pikiran-rakyat.com/nasional/2013/08/18/247050/ri-terlambatratifikasi-mlc-pelaut-terancam, diakses pada 9 Mei 2018.

Redaksional KPI, Ratifikasi MLC Terkatung-katung, http://www.kpiunion.org/ beritaratifikasi-mlc-terkatungkatung.html, diakses pada 13 Mei 2018.

Sandi, Andi Ant.T.T dan Agustina Merdekawati, "Konsekuensi Pembatalan UndangUndang Ratifikasi Terhadap Keterikatan Pemerintah Indonesia pada Perjanjian 
387 | Legitimasi Peraturan Pemerintah Pengganti Undang-Undang sebagai dalam Ratifikasi Perjanjian ...

Internasional". dalam Jurnal Mimbar Hukum, Volume 24, Nomor 23, Oktober 2012.

Sefriani, "Pengakhiran Sepihak Perjanjian Perdagangan Internasional" dalam PADJAJARAN Jurnal Ilmu Hukum, Volume 2 Nomor 1 Tahun 2015.

Sistem Informasi Perundang-Undangan Sekretariat Kabinet RI, http://sipuu.setkab.go.id/perjanjian internasional, diakses pada 4 April 2018.

Shanti Rahmadsyah, S.H., Status Hukum UU Ratifikasi", http://www.hukumonline.com/klinik/detail/lt4c69blcbd0492/status-hukum-uuratifikasi, diunduh 24 November 2017.

Wayan Parthiana, I, Hukum Perjanjian Internasional bagian 2. (Bandung: Mandar Maju, 2005). 
388 | LENTERA HUKUM

This page is intentionally left blank 